\title{
САХАРНЫЙ ДИАБЕТ В РЕСПУБЛИКЕ БАШКОРТОСТАН ПО ДАННЫМ ФЕДЕРАЛЬНОГО РЕГИСТРА БОЛЬНЫХ САХАРНЫМ ДИАБЕТОМ В 2017-2019 ГГ.
}

\author{
Байбурина Г.Г., Салахова Н.В., Павлов В.М.
}

Медицинский информационно-аналитический чентр МЗ РБ, Уфа, Россия

Сахарный диабет (СД) - социально-экономическое заболевание, распространенность которого стремительно растет и приводит к ухудшению качества жизни больных.

ЦЕЛЬ: изучить основные показатели качества жизни больных СД в Республике Башкортостан (РБ) в 2017-2019 гг. по данным Федерального регистра больных СД (ФРСД).

МАТЕРИАЛЫ И МЕТОДЫ: проанализированы данные ФРСД в РБ за 2017-2019 гг. Статистическая обработка полученных данных проводилась с использованием пакета прикладных программ Statistica for Windows V. 6.0.

РЕзУЛЬтАТЫ: с 2014 г. инициирован перевод ФРСД на online-программное обеспечение. Регистр трансформирован в современную электронную базу с авторизованным доступом, не требующую передачи данных локальных регистров. Отличительными чертами online-регистра является создание единой базы данных пациентов СД и возможность динамического мониторинга показателей на любом уровне от отдельного учреждения до области, региона и Российской Федерации (РФ) в целом.

По данным ФРСД России, по состоянию на 1 января 2018 г. в РФ зарегистрировано 4584575 больных СД, из них СД 1 типа: взрослых - 219 857, подростков - 9972, детей - 26373; СД 2 типа: взрослых 4237 291, подростков - 299, детей - 913, другие типы диабета - 89870.

Создание в 2001 г. в РБ ФРСД дало возможность оценить эффективность реализации указанной программы. ФРСД - это автоматизированная информационно-аналитическая система мониторинга эпидемиологической ситуации по диабету, качества лечебно-профилактической помощи, прогноза заболеваемости.

По данным ФРСД на 01.01.2020 г., в РБ на учете состоят 116588 больных СД, в том числе пациентов СД 1 типа - 7759, из них детей и подростков - 2217; СД 2 типа - 108829 человек, из них 27119 человек нуждаются в лечении препаратами инсулина, группу инвалидности имеют 24932 человек.

Структура СД в республике представлена следующим образом: СД 1 типа составляет 6,65\%, СД 2 типа 93,35\%. Распространенность СД в РБ растет за счет СД 1 и 2 типа. В 2017 г. распространенность СД в РБ на 100 тыс. населения составила 2622,8, а в 2019 г. - 2877,8, т.е. прирост за 3 года составил 9,7\%, в том числе СД 2 типа - 2451,4 и 2686,25 (+9,7\%) соответственно. Распространенность СД 1 типа достоверно выросла на 11,7\% и составила в 2017 г. и в 2019 г. - 171,5 и 191,5 соответственно.

Анализ общей заболеваемости по полу показал, что в 2019 г. в структуре СД 1 типа преобладали лица мужского пола - 55,1\%, а в 2017 г. - 55,6\%. Распространенность СД 1 типа среди мужского населения составила 205,1 на 100 тыс. в 2017 г. и 228,2 на 100 тыс. в 2019 г. (прирост +11,3\%), а среди женского населения - 144,2 и 159,2 на 100 тыс. соответственно, то есть выросла на 10,4\%. При СД 2 типа женщины болели в 2,1 раза чаще в 2017 г. и в 2 раза чаще, чем мужчины в 2019 г. Распространенность СД 2 типа среди мужского населения составила 1547,6 на 100 тыс. в 2017 г. и 1727,6 на 100 тыс. в 2019 г. (прирост +11,6\%), а среди женского населения - 3271,9 и 3531,7 на 100 тыс. соответственно (прирост +7,9\%).

Анализ эпидемиологической ситуации в РБ показал, что рост СД наблюдается за счет увеличения впервые выявленной заболеваемости (частоты), которая с 2017 г. по 2019 г. возросла на 22\% - 217,6 и 265,5 на 100 тыс. населения соответственно, что произошло как за счет СД 2 типа (+21,9\%) - 206,3 и 251,45 на 100 тыс. населения, так и за счет СД 1 типа на 24,8\%: 11,3 и 14,1 соответственно.

За период с 2017 г. по 2019 г. общая смертность больных СД на 100 тыс. населения увеличилась на 9,2\% и составила 92,7 и 101,2 соответственно. Смертность больных СД 1 типа не изменилась (3,6 в 2017 г. и 3,5 на 100 тыс. населения в 2019 г. соответственно), при СД 2 типа выросла на 10,2\% - 89,1 и 98,2 соответственно.

Средняя продолжительность жизни (СПж) больных СД отражает многие медико-социальные аспекты. СПЖ больных СД за последние три года остается на одном уровне: 2017 г. - 72,2 года; 2018 г. - 72,4 года; 
2019 г. - 74,4 года. При СД 1 типа в 2019 г. СПЖ составила 52,0 года (в 2017 и 2018 гг. — 54,4 года и 50,3 года соответственно), а при СД 2 типа - 73,1 года (в 2017 и 2018 гг. - 73,2 и 73,2 года соответственно).

Продолжительность жизни (ПЖ) больных СД от начала заболевания существенно не изменилась за 3 года и в 2019 г. составила 10,7 года, в 2017 и 2018 гг. - 10,2 года и 10,3 года соответственно. В 2019 г. ПЖ пациентов с СД 1 типа от начала заболевания - 18,4 года, а при СД 2 типа - 10,4 года.

ВыВОДы: общая заболеваемость СД в РБ растет как за счет СД 2 типа, так и за счет СД 1 типа; при СД 2 типа женщины болели в 2,1 раза чаще в 2017 г. и в 2 раза чаще, чем мужчины в 2019 г.; смертность больных СД возросла на 9,2\% за счет СД 2 типа в период с 2017 г. по 2019 г. СПЖ больных СД в 2017-2019 гг. не изменилась. 